\title{
Kategorie wiekowe filmów w publicystyce i listach do redakcji w latach 1970-1980
}

JAKUB ZAJDEL

Kategorie wiekowe do pewnego stopnia regulują dostęp do filmów. Tego spostrzeżenia nie trzeba obszernie opisywać, dlatego wyjaśnię jedynie powód, dla którego użyłem wyrażenia: „do pewnego stopnia”. Otóż kategorie wiekowe precyzyjnie ograniczałyby wstęp do kina niektórym grupom widzów, gdyby były ściśle przestrzegane. W praktyce tak nie było - w latach 70. XX w., o których będzie mowa, a zapewne i w innych dziesięcioleciach. $Z$ doniesień prasowych wiadomo - szerzej o tym napiszę na następnych stronach - że pracownicy kin wpuszczali na filmy widzów młodszych niż powinni. Również rodzice niekiedy domagali się, by ich dziecko obejrzało w kinie film przeznaczony dla wyższej kategorii wiekowej. Odpowiadając na interwencje w sprawie kategorii wiekowych, kierownicy kin zapewniali, że z obowiązku ich stosowania bileterki wywiązują się bez zarzutu. Trudno zatem ocenić, jaka była skala zjawiska omijania kategorii wiekowych. Czy była to rozpowszechniona i częsta praktyka, czy incydenty? Te wątpliwości sprawiają, że musiałem napisać o regulowanym częściowo, a nie w pełni dostępie do filmów w kinach.

Zamiarem moim jest przedstawienie różnych opinii na temat stosowania kategorii wiekowych w Polsce. W staraniach o zrealizowanie tego zadania sięgnąłem przede wszystkim do czasopism filmowych. Najwięcej informacji o kategoriach wiekowych dostarczał tygodnik „Film”. Zamieszczano w nim zapowiedzi nowych filmów zawierające wiek widza. Drukowano fragmenty listów od czytelników, w których znajdowały się uwagi dotyczące zarówno kwalifikacji wiekowych, jak i ich realizacji przez personel kin. Wreszcie w „Filmie” pojawiały się wypowiedzi osób odpowiedzialnych za kształtowanie granic wiekowych oraz związane z nimi komentarze.

Publikowane w gazetach programy kinowe były w interesującym mnie okresie podstawowym źródłem informacji o minimalnym wieku widzów, a dla mnie są ważnym dopełnieniem obrazu wyłaniającego się z wypowiedzi publicystów i widzów. Obszar obserwacji ograniczyłem do terenu Górnego Śląska, gdzie najbardziej dostępną gazetą była „Trybuna Robotnicza”. Jak można przeczytać w analizach prasoznawczych, gazeta o zasięgu wojewódzkim, jakim była „Trybuna Robotnicza”, pod względem wysokości nakładu konkurowała w latach 70. z „Trybuną Ludu", czyli z dziennikiem ogólnopolskim ${ }^{1}$. 
Zgłaszane w listach widzów i w publicystyce zastrzeżenia wobec systemu kwalifikacji wiekowej staram się zilustrować głównie na przykładach informacji o wyświetlaniu filmów polskich. Ponieważ jednak autorzy cytowanych publikacji często nie formułowali osobno uwag do kategorii wiekowych przyznanych rodzimej produkcji filmowej i produkcji zagranicznej, to sporadycznie posłużę się także przykładem filmu obcojęzycznego.

Warto zauważyć, że przypisanie filmowi określonej kategorii wiekowej z jednej strony może ograniczać dostęp do niego, a z drugiej - jeśli jest to niski pułap wiekowy - znacznie powiększać grupę widzów. To istotne powiększenie lub pomniejszenie grupy widzów dotyczy seansów dla szkół. W latach 70., gdy w szkołach podstawowych i średnich był powojenny wyż demograficzny, przesunięcie granicy wieku choćby o jeden rocznik powodowało duże zmniejszenie lub zwiększenie frekwencji na szkolnych seansach. W warunkach kinematografii państwowej, w której działania w zakresie organizacji widowni miały służyć realizacji celów wychowawczych polityki kulturalnej państwa, kategoria wiekowa była mocnym instrumentem programowania odbioru filmu.

Jednym z przykładów przesunięcia granicy wieku, które - jak można przypuszczać - znacząco wpłynęło na frekwencję, jest film Hubal w reżyserii Bohdana Poręby. W dniu premiery, 3 września 1973 r., wyświetlano go z kategorią „od czternastu lat” (kina: „Rialto”, Katowice; „Apollo”, Bielsko) 2 . Był to poniedziałek, dzień rozpoczęcia roku szkolnego. Kategorię tę utrzymano do środy włącznie. W repertuarze wydrukowanym 6 września 1973 r. (czwartek) można było przeczytać, że na opowieść o majorze Henryku Dobrzańskim mogą się wybrać już widzowie co najmniej jedenastoletni (kino „Rialto”, Katowice) ${ }^{3}$. Jednak zamiar wykorzystania filmu Poręby jako materiału pomocniczego do tematu: ,polski wrzesień 1939 roku” w niektórych przypadkach nie przynosił pożądanego rezultatu. W roku 1973 tygodnik „Film” zamieszczał porady repertuarowe dla widzów w wieku poniżej szesnastu lat. Osoba podpisująca się Z. Orski w publikowanych co miesiąc odcinkach cyklu pod tytułem Do lat szesnastu doradzała, który z filmów opatrzonych niższymi kategoriami wiekowymi warto wybrać. W grudniowym numerze został przytoczony fragment listu podpisanego Krzysztof G. z Bielska-Białej, w którym autor na podstawie swoich obserwacji zebranych podczas seansu filmu Hubal sygnalizował, że obniżanie granicy wieku niekiedy przynosi skutki odwrotne od zamierzonych: Obecna na sali grupa młodszych nastolatków przyjmowała film nader spontanicznie, co najmniej jednak nieodpowiednio. Ugodzony bagnetem Niemiec pada na ziemię: wybuch śmiechu. Gromada sterroryzowanych polskich chłopów spychana jest do dołu podczas pacyfikacji wsi, a później bestialsko mordowana; przerażony człowiek chwyta za buty żandarma: gromki, zaraźliwy śmiech. Kiedy byłem rówieśnikiem tych rozbawionych chłopców, takie sceny budzily we mnie przerażenie. Oni nie maja koszmarnych wspomnień, odbieraja film jak zwykly western. Nie maja pojęcia, kim byt Hubal i nic nie rozumieją. To nie ich wina, ale przecież wyrządza im się w ten sposób krzywdę... ${ }^{4}$ Odcinek cyklu Do lat szesnastu, w którym wydrukowano powyższy cytat, był podpisany przez Oskara Sobańskiego, który tłumaczył, że w grupie młodzieży od jedenastu do piętnastu lat można zaobserwować znaczne różnice $\mathrm{w}$ rozwoju intelektualnym. W celu podniesienia ogólnego poziomu nastolatków lepiej jest dostosowywać wychowywanie do poziomu bardziej dojrzałej części tej grupy niż chronić mniej dojrzałych za cenę infantyli- 
zacji ich rówieśników. Nawet jeśli rezultaty edukacyjne obniżenia granicy wieku dla filmu Hubal nie satysfakcjonowały w pełni decydentów, to duża liczba widzów musiała być powodem do zadowolenia. W zestawieniu wyników frekwencyjnych za okres od 1 kwietnia 1973 r. do 31 marca 1974 r. podano, że po trzydziestu tygodniach eksploatacji Hubal zgromadził 5955949 widzów ${ }^{5}$. Wśród filmów polskich zajmował drugie miejsce po filmie W pustyni $i$ w puszczy (19 171924 widzów) i przed Poszukiwany, poszukiwana, który obejrzało 1911021 widzów. Należy zauważyć, że liczba widzów na filmie Hubal rosła szybko do siedemnastego tygodnia jego eksploatacji w kinach, kiedy to sięgnęła $5274336^{6}$. Zapewne duży udział w tym sukcesie miały seanse szkolne, na które po obniżeniu kategorii wiekowej można było wysłać więcej klas.

\section{Kategorie wiekowe a widzowie Dyskusyjnych Klubów Filmowych}

Problem kategorii wiekowych należy również umieścić w kontekście kultury filmowej lat 70. Pomijając go, można by wysnuć przypuszczenie, że regulowano nimi jedynie dostęp widzów do filmów rozrywkowych, ponieważ filmy artystyczne trafiały do Dyskusyjnych Klubów Filmowych, do których uczęszczali dorośli. Otóż po zapoznaniu się z omówieniem raportu przygotowanego przez zarząd Polskiej Federacji Dyskusyjnych Klubów Filmowych na XII Zjazd należy definitywnie rozstać się z takimi opiniami. Relacjonując treść raportu, Elżbieta Smoleń-Wasilewska informowała, że w grudniu 1969 r. w Polsce było 271 klubów, 162 stałe i 109 kandydackich, a wśród nich znajdowały się również DKF-y młodzieżowe: ...nie można zapominać, że właśnie dzięki inicjatywie Federacji DKF wszczęto masowe akcje, jak choćby „,kino dla 900 tysięcy” pod patronatem Zwiazku Młodzieży Socjalistycznej, obozy filmowe prowadzone przez ZHP i ZSP, „,dyskusyjne kluby filmowe” na letniskach i zimowiskach Zwiąku Młodzieży Wiejskiej. (...) Statystyka podpowie, że około 90 klubów to DKF-y młodzieżowe (w szkołach i przy organizacjach takich, jak ZMS, ZHP, ZSP); 80 działa w środowiskach robotniczych przy zakładach pracy, hutach $i$ kopalniach; 55 - w powiatowych i miejskich domach kultury; 40 w wojsku ${ }^{7}$. Jak widać DKF-y młodzieżowe były najliczniejsze. Nie można więc mówić, że młodzież nie stykała się z filmami artystycznymi. Znaczy to, że kategorie wiekowe były jednym z ważnych czynników wpływających na repertuar DKF-ów.

Jakie grupy filmów prezentowane w DKF-ach mogły być zatem objęte kategoriami wiekowymi? Smoleń-Wasilewska wymienia cztery grupy: filmy archiwalne, filmy z puli specjalnej, polskie filmy przedpremierowe oraz filmy powtórkowe. Centralne Archiwum Filmowe dostarczało filmy archiwalne dla nie więcej niż stu DKF-ów. Pula specjalna, czyli filmy do rozpowszechniania tylko w DKF-ach i kinach studyjnych, w roku 1970 liczyła trzydzieści dwa tytuły, wśród nich osiem miało wkrótce stracić licencję. Procedura pozyskiwania filmów zagranicznych do puli specjalnej wyglądała następująco. Federacja sporządzała listę filmów, które powinny trafić do DKF-ów. Ich zakupem zajmowała się Centrala Wynajmu Filmów. Niestety realizacja zleceń niejednokrotnie rozczarowywała klubowiczów. Smoleń-Wasilewska odwołała się do przykładu: Oto los jednej z ostatnich list: obejmowała 150 tytułów, zatwierdzono 110. Centrala Wynajmu Filmów wszczęla zaś pertraktacje o trzy filmy (!). I nie o te, na których klubom szczególnie 
zależało ${ }^{8}$. Wreszcie - jak napisała Smoleń-Wasilewska - gdyby filmy przedpremierowe były dostępne dla DKF-ów, trafiałyby jedynie do kin w miastach wojewódzkich. Wojciech Wierzewski, wiceprzewodniczący PFDKF, wyjaśnił, że te trzy filmy, o których wspomniała Smoleń-Wasilewska, już weszły na ekrany i rozpoczęły się rozmowy w sprawie dalszych ośmiu filmów z listy ułożonej przez klubowiczów ${ }^{9}$. Natomiast idea prezentowania w DKF-ach polskich filmów przedpremierowych wciąż była torpedowana (Wierzewski nie wyjaśnia ani przez kogo, ani dlaczego ${ }^{10}$. W podsumowaniu opisu raportu o działalności DKF-ów Smoleń-Wasilewska zaznaczyła, że rezultatem kłopotów repertuarowych było zjawisko budowania przez DKF-y programów złożonych głównie z tytułów powtórkowych, czyli takich, które wycofano już z ekranów. Należy zwrócić uwagę, że filmy archiwalne i powtórkowe miały już przyznane wcześniej kategorie wiekowe - co oznacza, że podział wiekowy w DKF-ach przy ich wyświetlaniu nie odbiegał od reguł obowiązujących pozostałe kina. Pokazów przedpremierowych filmów polskich nie było, a więc nie było formuły, która z racji specjalnego trybu prezentacji zawieszałaby ograniczenia wiekowe.

Krytyczną - jeśli można je tak określić - grupą były natomiast filmy zagraniczne z puli specjalnej. Zmiany obyczajowe zachodzące w kulturze zachodniej wpływały na treść filmów i sposoby jej wyrażania. Szczególnie jaskrawo zjawisko to było widoczne właśnie w odniesieniu do filmów artystycznych ${ }^{11}$, czyli trzonu repertuaru klubowego. Filmy te najczęściej otrzymywały najwyższe kategorie wiekowe. Moim zdaniem można wysunąć tezę, że działacze i członkowie DKF-ów borykali się z takimi samymi wątpliwościami w stosunku do ograniczeń wiekowych, jak inni widzowie. DKF-y nie były ani kinem dla dorosłych, ani działalnością prowadzoną według specyficznych zasad poza systemem klasyfikacji wiekowej filmów. Wprowadzanie do ich programów filmów dla starszych klubowiczów niewątpliwie ograniczało edukację filmową wśród najcenniejszej grupy widzów, czyli młodzieży zainteresowanej sztuką filmową.

\section{Przed czym chronić nieletnich widzów?}

Dodatkowym wspomnianym już czynnikiem wpływającym na kategorie wiekowe był fakt, że w latach 70. wchodził w dorosłość powojenny wyż demograficzny. Na początku listopada 1970 r. ukazał się w „Filmie” artykuł Kazimierza Żygulskiego, w którym autor - socjolog kultury - zwrócił uwagę na rezultat, jaki to zjawisko będzie miało dla kinematografii polskiej. Podkreślił, że w nadchodzącym dziesięcioleciu w kinach będą dominowali młodzi dorośli oraz nieletni. Żygulski pisał: W ciagu najbliższego dziesięciolecia podstawowa masę widzów w kinach stanowić będzie młodzież pomiędzy 15 i 25 rokiem życia. W roku 1980 wiek 25 lat osiagnie rocznik urodzony $w$ 1955, piętnastolatki będa z rocznika $1965^{12}$. Jednocześnie zaznaczył, że niewielka grupa młodych aspiruje do wyższego poziomu wykształcenia: Wedtug perspektywicznej prognozy na rok 1980, opracowanej przed kilku laty przez znanego specjaliste, profesora A. [Antoniego] Rajkiewicza, na przewidywana liczbę 28 milionów dorostych Polaków, wyższe wyksztatcenie mieć będzie 3,5 procent (milion osób), przy czym w 80 procentach będzie to wykształcenie techniczne. Większość dorostych - 65 procent będzie miała wyksztatcenie podstawowe, petne i niepetne, 13 procent zawodowe, 18,5 procenta 
średnie-ogólnokształcace $i$ zawodowe ${ }^{13}$. Żygulski argumentował, że tak ukształtowani potencjalni widzowie nie będą chcieli oglądać filmów trudniejszych, wymagających kompetencji kulturowej.

Tekst Kazimierza Żygulskiego wywołał dyskusję na temat konieczności wychowania młodych widzów w kierunku uczestnictwa w filmowej kulturze artystycznej. W dyskusji o wychowaniu widza wzięli udział: Bolesław Michałek, Janina Koblewska, Anna Tatarkiewicz, Kazimierz Kutz, Andrzej Wajda i Krzysztof Zanussi ${ }^{14}$. Osobno wypowiedzieli się Kazimierz Żygulski ${ }^{15}$, Mikołaj Kozakiewicz ${ }^{16}$ i Alicja Helman ${ }^{17}$. Dyskutanci zgadzali się, że filmy artystyczne muszą przedstawiać problemy społeczne, polityczne i psychiczne bez uproszczeń oraz unikania nawet drastycznych obrazów. Zanussi stwierdził, że oczekuje od socjologów by zbadali, jak różni się wpływ filmu na widza dorosłego i nieletniego. Badania powinny dotyczyć przede wszystkim działania filmu $w$ dwóch najbardziej newralgicznych dziedzinach, jakimi sa przemoc $i$ seks ${ }^{18}$.

Redakcja „Filmu” w podsumowaniu dyskusji na temat wychowania widza zaznaczyła między innymi, że należy pamiętać o odróżnieniu widza dorosłego od nieletniego oraz widza dojrzałego od niedojrzałego. Jest to istotne dla ustalania kategorii wiekowych, ponieważ z jednej strony celem jest ochrona nieletnich przed treściami szkodliwymi, a z drugiej, czyli przy kategoriach widz dojrzały - niedojrzały, ważne jest, aby w obawie przed wyższą kategorią wiekową nie produkować wyłącznie filmowej strawy dla maluczkich, dla niedojrzatych emocjonalnie ${ }^{19}$.

W okresie istnienia Polskiej Rzeczpospolitej Ludowej widzowie nie byli informowani o łagodzeniu i upraszczaniu treści filmów przez wprowadzanie w nich zmian zaleconych przez różne gremia. Poruszanie w filmach tematów drażliwych politycznie lub obyczajowo blokowano już na etapie akceptacji scenariusza albo w trybie kolaudacyjnym nakazywano wycięcie niektórych fragmentów. Do wiadomości społecznej dochodziły czasami niepokojące sygnały, gdy z ekranu znikał film już dystrybuowany. Oto w roku 1970 zdarzyło się, że nawet wysoka bariera wiekowa i obieg dedykowany (w DKF-ach i kinach studyjnych) nie ochroniły tak zwanego filmu kontrowersyjnego. Andrzej Kaleta pisze, że jego zdaniem niesłusznie wycofano z kin film François Leterriera Ślad krwi (Un roi sans divertissement, 1963). Przecież film miał kategorię wiekową osiemnaście lat i był w kinach studyjnych, czyli w tych, których założeniem jest wyświetlanie filmów nawet najbardziej kontrowersyjnych i dyskusyjnych ${ }^{20}$. Ale zdjęto go z ekranu w reakcji na publikację w „Wieczorze Wybrzeża", w której lokalny recenzent stwierdził, że film namawia do przemocy.

Odnosząc się do problemu wychowywania przez film lub wychowywania z filmem, Kazimierz Żygulski ${ }^{21}$ podkreślił, że w socjalistycznym państwie program kinematografii powinien być kształtowany pod kątem masowego widza. Obrona wolności artystycznej za cenę filmów dla większości widzów jest postulatem negującym praktykę społeczną. Żygulski argumentował, że filmy będące odpowiednikami spektakli Jerzego Grotowskiego są potrzebne, ale należy pamiętać, iż pomimo rosnącego wykształcenia, szczególnie młodych Polek i Polaków - upodobania widzów nie są jednolicie ukierunkowane na artefakty kultury wysokiej. Znaczyło to, że większość widzów filmowych pomimo wymaganej przepisami liczby lat i dojrzałości emocjonalnej nie posiadała kompetencji kulturowej, która motywowałaby ich do poszukiwania w kinach filmów nieschematycznych, nieuproszczonych, niewyłagodzonych. 
W numerze „Filmu” z 1 października 1972 r. zabrał głos Henryk Depta, który właśnie objął stanowisko przewodniczącego Komisji do Spraw Kwalifikowania Filmów dla Dzieci i Młodzieży. Przypomniał obowiązujące wówczas kategorie wiekowe: 7, 11, 14, 16 i w wyjątkowych wypadkach - 6 i 18 lat $^{22}$. Stwierdził, że zdaniem komisji nie odpowiadają one współczesnej sytuacji społecznej oraz dojrzałości psychicznej młodych. Biorąc pod uwagę ówczesną wiedzę na temat rozwoju intelektualnego i emocjonalnego człowieka oraz programy nauczania realizowane w szkołach, komisja zaproponowała nowe kategorie: filmy dozwolone od siedmiu, jedenastu, piętnastu $i$ - wyjątkowo osiemnastu lat ${ }^{23}$. Można by też obniżyć wiek o dwa lata, jeśli opiekunowie oświadczą, że decyzję o wyborze filmu wezmą na swoją odpowiedzialność. Natomiast w przypadku grup zorganizowanych odpowiedzialnością zostaliby obarczeni wychowawcy. Przy ustalaniu granic wiekowych komisja kierowała się trzema kryteriami: 1. stopień rozwoju intelektualnego; 2. stopień rozwoju emocjonalnego; 3. stopień pożądanych lub niepożądanych wychowawczo treści. Depta zapewnił, że komisja zdaje sobie sprawę, że formuła ,film dozwolony od lat..." jest (...) schematyczna, określa jedynie fizyczny wiek widza, który nie zawsze musi iść w parze z jego poziomem inteligencji $i$-jeśli można tak powiedzieć - wiekiem moralnym ${ }^{24}$. W podsumowaniu Depta stwierdził, że działalność Komisji jest działalnością wychowawcza ${ }^{25}$. Prowadząc ją, Komisja nie powinna ulegać presji rzeczywistości, bo wtedy przestanie wypełniać swoją rolę wychowawcy, a z drugiej strony Komisja nie może wychowywać wbrew doświadczeniu, jakie młodzi już mają (młodzi znają przemoc z obserwacji lub doświadczeń codziennych).

Po siedmiu miesiącach, pod koniec kwietnia 1973 r. Depta ${ }^{26}$ wyjaśnił swój pogląd na wychowanie za pośrednictwem filmu. Argumentację rozwinął wokół jednego $\mathrm{z}$ aspektów przedstawiania filmowego, który wcześniej wymieniła Alicja Helman ${ }^{27}$, zabrawszy głos w sprawie wychowywania widza filmowego. Helman zwróciła uwagę, że najczęściej negatywnymi bohaterami dyskusji o wychowawczej roli filmu są seks i okrucieństwo: Jeśli film przedstawia zjawiska z tej sfery-jest szkodliwy, podejrzany lub co najmniej dyskusyjny. Jeśli nie - jest pożyteczny lub neutralny. Seks i okrucieństwo w filmie nie sa problemem dajacym się uogólnić, ale znam wiele filmów, w których oba te czynniki odgrywaja rolę istotna, które jednakże, gdyby przyszło mi je zakwalifikować z pedagogicznego punktu widzenia, określitabym jako głęboko moralne ${ }^{28}$. Należy jednak pamiętać, że wiele szkody wyrządzają również filmy zachęcające do fałszywego psychicznego komfortu ${ }^{29}$; filmy, które sugerują, iż artyzm ogranicza się do perfekcji technicznej; kicz filmowy oraz filmy, które potrafią uprawdopodobnić kłamstwo. Właśnie do tego ostatniego aspektu odwołał się Henryk Depta. Zaprezentowane przez niego rozumowanie można zrekonstruować następująco: w XX w. film najszerzej i najpełniej ze wszystkich sztuk nawiązuje kontakt emocjonalny z odbiorcą; młodzież czerpie wzorce zachowań, dewizy życiowe i postawy z oglądanych filmów; percepcja wzrokowa stymuluje wiarę w to, co się widzi; niestety, w wielu filmach obrazy ukrywają mistyfikację. Rolą wychowawców jest zatem takie podejście do młodego widza, by uczyć go umiejętności konfrontacji filmu z rzeczywistościa, polecać mu takie filmy, które zachowując petne prawo autora do własnej wizji świata, ukazujac rzeczywistość w całej jej różnorodności, pozostaja jednocześnie jej wierne ${ }^{30}$. Ta deklaracja programowa zapowiadała, że niższe kategorie wiekowe będą uzyskiwały filmy „wierne rzeczywistości" - uznawane za najbezpieczniejsze. 


\section{Lęk przed erotyką w filmie}

W latach 70., tak jak i wcześniej, dochodziły do czytelników prasy polskiej opisy degradacji obyczajów w kręgu kultury zachodniej, a szczególnie w USA. Pisano $\mathrm{w}$ tonie potępiającym o tamtejszym upadku wartości moralnych, który był widoczny także w filmach. W korespondencji z USA Michael Beam opisał rozpad obowiązującego tam systemu kwalifikacji wiekowej: Widać to najlepiej po filmach, które jeszcze kilka lat temu wywoływały zgorszenie. Oto komedia Billy Wildera „,Kiss me, stupid” (,Pocałuj mnie, gtuptasie”) została w roku 1965 zaliczona przez cenzurę kościelna do kategorii "C" (condemned), czyli do „filmów potepionych". Niedawno film ten wznowiono, ale tym razem zostat zaliczony do kategorii „, G”, czyli do ,filmów rodzinnych", a więc dostępnych nawet dla dzieci ${ }^{31}$.

W Polsce zmiany obyczajowe nie były manifestowane w sferze społecznej i artystycznej tak mocno jak w USA, ale również postępowały. Można je było dostrzec na przykład w prośbach widzów o większą tolerancję dla nagości i scen erotycznych w filmach. Widzowie zwracali uwagę, że obrazy przemocy są powszechnie spotykane w filmach opatrzonych niższymi kategoriami wiekowymi, a nawet delikatnie pokazany pocałunek lub akt kobiecy jest rezerwowany dla co najmniej starszych nastolatków. Czytelnik „Filmu”, Zbigniew Tarkowski ze Złocieńca, pisał: ... klasyfikacja filmów dla dzieci i dorostych w obecnej formie jest anachronizmem. Pozostawia się sceny odrabywania rąk, głów, dokładne analizy ran kłutych, ciętych i szarpanych. Po wycięciu scen obfitujących w szczegóty anatomiczne kobiecego ciała, filmy petne okrucieństw aplikuje się dzieciom (bo wydaje mi się, że czternastoletni widz jest jeszcze dzieckiem). Takie traktowanie dorosłego widza nie pozwala mu na obejrzenie wielu filmów w całości, doskonale natomiast zniechęca go do pójścia do kina ${ }^{32}$. Piętnastoletni widz podpisany M. M. z Gliwic pisał: Do napisania tego listu sktonit mnie film „Agent nr 1", po obejrzeniu którego nasuwa mi się kilka pytań. Jeżeli na ekranie chłopiec pieści swoja dziewczynę (,, Kto wierzy w bociany”, ,Seksolatki”-dozwolone od lat 16), czy jest to bardziej deprawujace od oglądania zmasakrowanej, zakrwawionej twarzy, bestialskiego kopania więźnia przez SS-mana, katowania nagiej dziewczyny? (,,Agent nr 1”, , Hajducy kapitana Angela" - od 14 lat). Co może bardziej negatywnie wptynać na widza: obraz kochajacej się pary czy pastwienie się jednego człowieka nad drugim? ${ }^{33}$

Pod koniec lutego 1972 r. w „Tygodniku Powszechnym” ukazał się artykuł Zbigniewa Lwa Starowicza ${ }^{34}$ na temat erotyzacji kultury masowej. Jeden z wątków dotyczył wpływu erotyki filmowej na młodzież. Starowicz zaznaczył, że pomija film artystyczny z powodu wąskiego kręgu jego widzów. Natomiast w stosunku do filmów dla szerokiej widowni wysunął tezę, że większość młodych czerpie z filmów wzory postaw seksualnych. Film dominuje w tej sferze doświadczenia, ponieważ rodzice i szkoła w większości nie podejmują wychowania seksualnego. W niektórych czasopismach młodzieżowych pojawiają się informacje o seksualności człowieka, ale ich nakłady są tak niskie, że docierają do niewielkiej liczby odbiorców. Telewizja tę problematykę zupełnie pomija. Zdaniem Starowicza w zakresie powszechności prezentacji postaw i zachowań seksualnych film nie miał konkurencji na początku lat 70. Gdyby obrazy filmowe oferowały młodzieży pozytywne wzorce, to nie budziłyby obaw, ale większość filmów kultury masowej jest poświęcona tematyce z kręgu patologii obyczajowej: trójkąty, gwałty, perwersje, 
zdrady, wspólżycie poza wszelkimi ograniczeniami stanowia lwia część tematyki filmów. Lawina bodźców seksualnych o negatywnej treści nie tylko uaktywnia podświadomość, ale prowadzi do autonomizacji seksu, który wtedy staje się coraz bardziej agresywny, dążac do zaspokojenia mimo wszystko $i$ mimo wszystkiemu ${ }^{35}$. Wniosek był jednoznaczny: większość scen erotycznych w filmach ma negatywny wpływ na młodzież. Sposobem na jego złagodzenie, zdaniem Starowicza, było prowadzenie dyskusji o seksualności w rodzinach i w szkole.

Wykonany w ciemnych barwach szkic Starowicza odnosił się głównie do zachodniej kultury masowej i tamtejszych filmów. W opinii seksuologa kino polskie było w tym względzie zapóźnione. Starowicz pisał: Nagość pojawia się w naszych filmach nieśmiało, ale konsekwentnie i z wyraźna ewolucja ,obszaru wolnego ciała" ${ }^{36}$. Również krytycy filmowi zauważyli, że w na początku lat 70 . pojawiło się w polskich filmach więcej nagości i erotyki. Jednak skala zjawiska nie była ich zdaniem największym problemem. Zasadniczą pretensję wobec erotyki w polskim filmie Maciej Karpiński ujął następująco: (...) każdy bez trudu zauważy, że śmiałość polskich filmów jest niczym $w$ porównaniu z analogicznymi obrazami w filmach zachodnich, wyświetlanych i na naszych ekranach. Dlaczego więc to zjawisko powoduje tyle szumu i budzi zaniepokojenie także ludzi świattych, którym chodzi o poziom polskiej kinematografii? Cecha wyróżniajaca polski erotyzm filmowy jest bowiem bezsensowność ${ }^{37}$. Karpiński twierdził, że sceny erotyczne są wprowadzane do fabuł polskich filmów bez żadnego uzasadnienia dramaturgicznego. Reżyserzy traktują je jak atrakcję, niezbędną do przyciągnięcia również tej części widzów, dla których treść filmu nie ma większego znaczenia.

Tygodnik „Film” publikował listy czytelników, którzy w sprawie erotyki w polskich filmach mieli zdanie odmienne od opinii krytyków. W jednym z takich listów (podpisanym „dr K. Ł.”) można przeczytać: Ale ja twierdzę, że-może z wyjątkiem „Szerokiej drogi, kochanie” - w filmach polskich ta delikatnie ukazana nagość zawsze kojarzy się: albo z miłościa, albo odmalowuje środowisko $i$ wtedy ma charakter satyryczny (jak w , Tradzie”), albo wreszcie odmalowuje charakter czy cechy bohaterki (jak w ,,Rewizji osobistej”). Wszędzie - o ile pamiętam - „nagość” jest organicznie wpleciona w fakture filmu. Na taka ,Film” się chyba zgadza? Zwłaszcza że - podkreślam - u nas sceny te sa zawsze petne umiaru i artyzmu ${ }^{38}$. Pięć tygodni później wydrukowano w „Filmie” dwa listy, które były reakcją na opinię zaprezentowaną przez „K. Ł.”, ale wyrażały skrajnie różne opinie. J. C. z Rzeszowa oburzył się na propagowanie erotyki, ponieważ każdy poważnie myślacy człowiek widzi, co się dzieje w związu z ta rewolucja seksualna, jak spada poziom moralny ${ }^{39}$. Natomiast osoba podpisana „St. L. z Oświęcimia” ubolewała, że (...) od lat drepczemy w miejscu, choć bardzo chętnie poszlibyśmy dalej ${ }^{40} \mathrm{~W}$ sprawie rozpowszechniania erotyki w mediach.

Kwestię uwzględnienia wpływu erotyki na nieletnich w kwalifikacji wiekowej filmów poruszył Mikołaj Kozakiewicz. Argumentował, że wpływ filmu należy rozpatrywać wraz z oddziaływaniem na daną osobę wielu innych czynników. Pojedynczy film niczego nie zmieni w postawach i zachowaniu. Może natomiast wzmocnić postawy, z którymi widz zetknął się w procesie wychowania, w codziennym życiu i w innych sztukach. Można nakłonić osobę nieletnią do obejrzenia filmu, w którym bohaterowie będą prezentowali szczyty szlachetności, uczciwości i poświęcenia, ale jeśli tych postaw nie będzie w jej otoczeniu, to należy się spo- 
dziewać, że film zostanie przez nią wyśmiany i odrzucony. Zastanawiając się nad kryteriami przyznawania metryczek wiekowych, Kozakiewicz pisze: U podłoża ich leży przede wszystkim antyseksualna obsesja dziewiętnastowiecznej pedagogiki. Klucz owych metryczek można (przerysowują) przedstawić następujaco: w filmie nie ma nic z ,tych rzeczy" (ale poza tym strzelaja się, wieszaja, wbijaja na pal, miażḋa czołgami itd.) - dozwolony od lat 7; w filmie jest kilka pocałunków, niezbyt namiętnych i dogtębnych - dozwolony od lat 14; w filmie jest sporo namiętnych pocatunków, ale jeszcze brak scen „, tózkowych” lub „plenerowych”, wiadomo $z$ akcji, że aktorzy ,to robia”, ale się tego dokładnie nie pokazuje, najwyżej aluzyjnie - dozwolony od lat 16; robia to $w$ kadrze! widać, że ona jest gota i że on jest goty! sapia i jęcza - dozwolony od lat $18 !^{41}$

\section{Trzecia czesść nocy, czyli czego nie było wolno w aktorskim filmie fabularnym}

Mikołaj Kozakiewicz w żartobliwy sposób przedstawił sposób oceniania typowych scen filmowych, w których seksualność budzi kontrowersje, ale nie należy do sfery tabu. Tymczasem na początku 1972 r. pojawił się w kinach film Trzecia część nocy w reżyserii Andrzeja Żuławskiego, który jedną sceną - porodu sfilmowanego w konwencji filmu oświatowego - przekreślił uspokajające przeświadczenie, że problematyka seksualności wyczerpuje się w erotyce. Film wyświetlano z kategorią od lat osiemnastu (kino „Rialto”, Katowice) ${ }^{42}$. Taka kwalifikacja była spowodowana zapewne nie tylko wspomnianą przeze mnie sceną. Film był skomplikowany w warstwie symbolicznej i narracyjnej ${ }^{43}$, a jednocześnie odsyłał do czasu okupacji hitlerowskiej. Potencjalnie więc temat należał do kanonu programu edukacji szkolnej. Nauczyciele mogliby więc dyskutować o nim z uczniami starszych klas licealnych, którzy w ówczesnym systemie nauczania osiągali już wymagany wiek.

4 października 1971 r., a więc trzy miesiące przed premierą Trzeciej części nocy, odbyło się spotkanie Andrzeja Żuławskiego i Małgorzaty Braunek ze studentami ${ }^{44}$. Opisując swoje wrażenia po projekcji filmu widzowie używali takich słów, jak krew, śmierć, okrucieństwo, drastyczność, szok i poród. Umieszczenie porodu w tym szeregu nazw sugerowało, że scena, w której został on pokazany, wywołała w nich silne emocje, a właściwie należy napisać: silniejsze niż zwykle. Znaczy to, że widzowie zobaczyli coś, na co nie byli przygotowani. Stanisław Grzelecki posłużył się określeniem: brutalna dosłowność ${ }^{45}$. Rafał Marszałek, Janusz Zatorski i Anna Tatarkiewicz napisali o naturalistycznej scenie porodu ${ }^{46}$. Jerzy Ambroziewicz zwrócił uwagę na wyeksponowanie w filmie aspektu fizjologicznego ludzkiej cielesności: Krew tryska z każdej części ludzkiego ciała, pod razami kolb i pod kulami, a także w czasie porodu. Preparowane, nażarte krwia wszy mają na ekranie wielkość bawołu, nabrzmiałe żyly rodzacej średnicę przewodów kanalizacyjnych, a główka rodzącego się dziecka wychodzi z miejsca, z którego naprawdę bierze początek życie ${ }^{47}$. Wreszcie pojawiły się głosy, że pokazywanie porodu jest wyrazem braku dobrego smaku. Żuławski skonfrontowany z tą opinią, stwierdził, że po pierwsze kino ze swej istoty balansuje na ostrzu między bezguściem a estetyza$c_{j a}{ }^{48}$, a po drugie - kierowanie się regułami dobrego smaku zabija ewolucję sztuki. Natomiast na zarzut, że scena porodu jest pokazana naturalistycznie, Żuławski od- 
parł: To nie naturalizm, to p r a wd a. Jeżeli realizuję film o chłopaku, który pierwszy raz trzyma w ręku dziecko - to musi to być rzeczywiste dziecko, a nie pojęcie dziecka. Scena porodu, która wzbudziła wśród mężczyzn tyle wątpliwości, a nieraz i obrzydzenia - wśród kobiet z kolei wywotuje często niekłamany zachwyt ${ }^{49}$. W „Filmie” wydrukowano dwa listy wspierające reżysera. Osoba ukryta za inicjałami A. P. stwierdziła, że normalnie reagujacy człowiek powinien odczuć poród jako zjawisko naturalne, natomiast widok zabójstwa - jak rzecz przerażajaca ${ }^{50}$. Z kolei Andrzej Kamieński, który - jak sygnalizuje w tekście, obserwował młodzież w czasie seansu - zapewniał, że młodzi byli wstrząśnięci nie tyle brutalnością widowiska, ile emanującą z filmu prawdą życia. Natomiast samo pokazanie młodym ludziom porodu musiało być dla nich silna lekcją życia, zwłaszcza że udzielona na tle życia, a nie $w$ ramach ćwiczeń klinicznych ${ }^{51}$. Do zarzutów wobec Trzeciej części nocy obszernie odniósł się Mariusz Hermanowicz, czytelnik miesięcznika „Kino”. Naturalizm sceny porodu nie był dla niego przeszkodą w dostrzeżeniu afirmacji życia: Ja, oglądajac tę scenę, uświadomiłem sobie po raz pierwszy z taka sita, ile bólu kosztuje danie nowego życia. Pokazuje [ta scena], jak wielkim, znaczacym faktem jest poród. Przecież tu rodzi się człowiek. A my jesteśmy na to obojętni! A fe! - jaki naturalizm, mówimy. A może to my jesteśmy mało wrażliwi? Może nie potrafimy dostrzec uśmiechu szczęścia na twarzy matki, gdy rodzi się jej dziecko? Bo to nie jest twarz tylko wykrzywiona bólem, jest też ona ,wykrzywiona” szczęściem, które powstaje, i może powstać tylko przez ten ból. A my powiadamyjakie to szokujace ${ }^{52}$.

Negatywna ocena przypisana przez krytyków scenie porodu prowokuje do zastanowienia. Równolegle bowiem pojawiały się w prasie publikacje, w których na przykład Lech Pijanowski i Leon Bukowiecki wyrażali swoją aprobatę dla filmów popularno-oświatowych o tematyce seksualnej. Lech Pijanowski pisał: Oczywiste jest, że nie można z ekranu kina uczyć fizjologii płci skutecznie i nowocześnie, nie pokazując narządów ptciowych; nie można uczyć technologii stosunków seksualnych, nie pokazujac tychże. Wszystko jest więc pokazane, co stanowi sensowne wykorzystanie możliwości kina, jeśli założyć jego wykorzystanie do takich właśnie celów ${ }^{53}$. Obaj krytycy twierdzili, że filmy służące edukacji seksualnej są jak najbardziej potrzebne i nie ma żadnych przeciwwskazań dla ich rozpowszechniania w Polsce. Niestety nie wspominali przy tym o granicy wieku, która powinna regulować ich dostępność, więc nie wiadomo jakiego widza mieli na myśli. Dyskusja o scenie porodu w Trzeciej części nocy sugerowała, że problematyka seksualności ukryta za zasłoną erotyki czeka dopiero na swój czas i być może konieczne będzie znacznie głębsze przemyślenie kategorii wiekowych przyznawanych filmom.

\section{Niezrealizowana zapowiedź uproszczenia systemu kategorii wiekowych}

Niewątpliwie nagość i erotyka stanowiły istotny problem dla systemu kwalifikacji wiekowej filmów, ale nie jedyny. Od strony praktycznej, czyli z punktu widzenia rodziców i bileterek zastrzeżenia budziła jego drobiazgowość. W numerze z 9 grudnia 1973 r. pod tekstem kolejnego odcinka z cyklu Do lat szesnastu widniał podpis: Oskar Sobański. Obok wskazówek dotyczących bieżącego repertuaru kinowego autor zapowiadał zmiany w systemie kategorii wiekowych: Nasz system 
dotychczasowy jest najbardziej skomplikowany na świecie - i bodaj przez to najgorzej przestrzegany. Mamy filmy dozwolone od lat 7, 11, 14, 16 i 18, ale sa tez filmy dozwolone od lat 6 i 9. Wrruszajaca jest zaiste precyzja, z jaka komisja przy CWF rozstrzyga, że „Bułeczka” nie zaszkodzi sześciolatkom, zaś „Pippi w krainie Taka-Tuka” stanowi dla nich poważne zagrożenie, wobec czego moga ogladać ja dzieci aż siedmioletnie. Taki przykład mamy $w$ repertuarze grudnia ${ }^{54}$. Sobański poinformował również, że uproszczenie podziałów wiekowych przybliży naszą kinematografię do innych kinematografii obozu socjalistycznego: dla przykładu w Bułgarii i ZSRR jest tylko jedna granica wieku: 16 lat ${ }^{55}$.

Rzeczywiście czytelnicy „Filmu” w listach do redakcji zgłaszali przypadki naruszania kategorii wiekowych w kinach. I na koniec - obrazek z jednej niedzieli (13 lutego). W kinie „Polonia” wyświetlany byt film japoński „Beczka prochu”, dozwolony od 16 lat. Nie dostałam biletów, bo pod kasa thum 9-11 letnich dzieci. Wszystkim sprzedano bilety $i$ wszystkie weszły na sale projekcyjna. A co robia $w$ niedziele nauczyciele, skoro personel kina decyduje o wpuszczaniu dzieci na niedozwolone filmy? ${ }^{56}$ - pisała Stenia Tumidajewicz z Ełku. W odpowiedzi Kierownictwo Kina „Polonia” w Ełku wyjaśniło: W naszym kinie wyświetlamy wiele filmów dozwolonych powyżej 16 lat. Wpuszczanie na nie dzieci poniżej określonej granicy wieku jest karalne, na co kierownictwo i personel zwraca szczególna uwage ${ }^{57}$. Z kolei Janusz Czerniakowski pisał: 30 maja $w$ warszawskim kinie „Reduta” wyświetlany byt ,Zwariowany weekend”. Widownia w przeważajacej większości składała się z rozbrykanych dzieci (z których większość na pewno nie miała 11 lat), puszczonych zupetnie samopas ${ }^{58}$. Cytowany już przeze mnie M. M. z Gliwic ${ }^{59}$ poinformował o swobodnym traktowaniu przez pracowników kina przepisów dotyczących wieku widzów. Należy przypomnieć, że M. M. był piętnastolatkiem. Pisał, że jego rówieśników, którzy są wyżsi od niego, bileterki wpuszczają na filmy od lat szesnastu. Pozwolono mu wejść na film Agent $n r 1$, który był wyświetlany o godzinie 19.30, a przecież zgodnie z przepisami młodzież może uczestniczyć w wieczornych seansach tylko pod opieką dorosłych. Autorzy niektórych listów wyrażali przypuszczenie, że pracownicy kin sprzedają bilety widzom niezależnie od ich wieku w celu podniesienia wyników frekwencyjnych.

Wreszcie poinformowano, że od 1 października 1974 r. będą obowiązywały trzy kategorie wiekowe: (...) filmy dozwolone dla wszystkich, bez określenia dolnej granicy wieku; filmy dozwolone dla widzów powyżej 15 lat; filmy dozwolone dla widzów powyżej 18 lat $^{60}$. Komentując to rozporządzenie Ministra Kultury i Sztuki, Oskar Sobański stwierdził, że obecne kryteria sq - jak się zdaje-lepiej dostosowane do całego systemu wprowadzania młodych ludzi w życie: 15 lat - to wiek kończenia szkoły podstawowej, wiek w którym większość młodzieży ma już za soba pierwszy etap okresu dojrzewania; 18 lat - to wiek dojrzałości prawnej ${ }^{61}$.

Szybko okazało się, że w codziennej praktyce nowe kategorie wiekowe również sprawiają problemy. Rzecz jasna dotyczyły one nie tylko filmów polskich, na których skupiłem uwagę. Pominę zatem sygnały o filmach z napisami oznaczone kategorią „,bez ograniczeń wiekowych” ${ }^{62}$ i wymienię jedynie przykładowo te, które dotyczyły zarówno filmów obcojęzycznych, jak i polskich. Osoba podpisana Zrezygnowany pisała: Mamy w Kruszwicy jedno jedyne kino „, Gopło”, dwie gospody $i$ dwie kawiarnie. Kino od 1 października do 30 września gra tylko jeden seans dziennie, o godz. 20. Regulamin uczniowski postanawia, że w okresie letnim 
uczniom wolno przebywać poza domem tylko do 21, seans kończy się o 22-22.15. (...) A tymczasem coraz więcej filmów dozwolonych jest od 15 lat lub bez ograniczeń wieku ${ }^{63}$. Z kolei o późniejsze godziny seansów dla dzieci upomniał się ojciec ośmiolatka, Bronisław Kamiński: Filmy dla dzieci grane sa w Warszawie wyłącznie na seansach rannych $i$ wczesnym popoludniem, najpóźniej do 15-15.30. W ten sposób rodzicom, którzy pragna pójść razem z dziećmi do kina odbiera się wszelkie szanse, bowiem rodzice o tej porze pracuja ${ }^{64}$. Zdaniem Kamińskiego argument, że można wybrać się do kina w sobotę lub w niedzielę, nie rozwiązuje sprawy. Właśnie w tygodniu wygodniej jest poświęcić dwie godziny na obejrzenie filmu niż w weekend. Rodziny bardzo często spędzają dni wolne poza miastem lub uprawiając sport. Gdyby kina systematycznie wyświetlały filmy dla dzieci o godzinie 17.00 lub 18.00 , to niewątpliwie mogłyby liczyć na wysoką frekwencję. W notce pod listem Kamińskiego redakcja „Filmu” potwierdziła, że pretensje rodziców w sprawie godzin seansów dla dzieci powracają regularnie, ale niestety kierownictwo stołecznego Przedsiębiorstwa Rozpowszechniania Filmów nie wprowadza postulowanych zmian.

Rzeczywiście temat niedostosowania godzin seansów do czasu wolnego rodziców powracał latami. Wystarczy przypomnieć list podpisany M. G., Wrocław ${ }^{65}$, w którym autorka lub autor informował, iż film Abel, twój brat jest wyświetlany we Wrocławiu nie dość, że w kinie studyjnym, to jeszcze w godzinach pracy. List został wydrukowany w „Filmie” z 5 września 1971 r., a więc mniej więcej sześć lat przed listem Bronisława Kamińskiego. W tym czasie udało się przeprowadzić zmiany kategorii wiekowych, ale - wbrew intencjom ich inicjatorów - nie ułatwiło to najmłodszym widzom dostępu do filmów kinowych.

W obszernym omówieniu zasad, jakim powinien podlegać repertuar kin, Aleksander Ledóchowski odniósł się również do filmów polskich. Zwrócił uwagę na dwa zjawiska. Po pierwsze, bezrefleksyjne korzystanie przez nauczycieli z możliwości wprowadzenia seansu szkolnego do programu nauczania. Niektóre szkoły zorganizowały wyjścia na seanse Ziemi obiecanej Andrzeja Wajdy, pomijając ocenę poziomu dojrzałości emocjonalnej i intelektualnej uczniów, a przecież sa tam sceny erotyczne i brutalne, także ogólna wymowa dzieła wymaga pewnej dojrzałości ${ }^{66}$. Po drugie, wprowadzanie do filmów polskich pseudoslangu młodzieżowego i postaw kontrkulturowych, przeciwnych takim wartościom, jak rodzina, szkoła itp., oraz propagowanie postaw roszczeniowych musi być pod szczególnym nadzorem komisji przyznającej kategorie wiekowe. Jedenaście miesięcy później ukazał się artykuł, w którym Ledóchowski sformułował postulaty pozytywne między innymi w stosunku do filmu polskiego. Stwierdził, że chociaż zdarzają się niedopatrzenia, to kwalifikacja wieku filmów kinowych nie budzi z grubsza zastrzeżeń... ${ }^{67}$. Brakuje natomiast filmów, które wnosiłyby coś więcej, niż tylko spełnienie kryteriów narzuconych filmom dla młodych. O widzach należących do pokolenia powojennego wyżu demograficznego Ledóchowski pisał jako o zanurzonych $w$ smudze młodości ${ }^{68}$. Proponował, aby kino polskie stworzyło filmy, w których odnajdą siebie i jednocześnie zostaną zmuszeni do społecznego samookreślenia ${ }^{69}$ oraz pobudzeni do zmierzenia się z własnymi wątpliwościami. 


\section{Czy kategorie wiekowe były niezbędne?}

W połowie roku 1979 Oskar Sobański podsumował podejmowane od roku 1974 próby uproszczenia i dostosowania do rozwoju ówczesnych nastolatków systemu kwalifikacji wiekowej filmów. Zdaniem Sobańskiego pomimo zmian nie usunięto niezwykle silnej przeszkody, która hamowała propagowanie filmów z niższymi kategoriami wiekowymi. Jest nią podział na filmy dla dorosłych i dla dzieci. W rezultacie filmy dla dzieci, jako sztucznie wyodrębniona grupa, są wyświetlane na seansach, na które jakoby nie mogą przyjść dorośli. Skutkiem jest niska frekwencja, bo przecież znaczna część najmłodszych widzów nie może samodzielnie wybrać się do kina. W Anglii zauważono potrzebę umożliwienia i zachęcenia dorosłych do wspólnego z dziećmi uczestnictwa w seansach filmowych. Podejście to zostało wyrażone w obowiązujących tam kategoriach: $U$-filmy dla wszystkich, AA - dla dzieci, którym towarzysza dorośli, $X$-tylko dla dorostych ${ }^{70}$. Sobański postulował, aby w następnych latach tak układać repertuar, by rozwinęła się instytucja kina rodzinnego.

Jednak gdy przegląda się ofertę programową kin z końca 1979 r., szybko staje się jasne, że pomimo dyskusji w gronie specjalistów oraz publikowania listów od widzów zmiany w systemie kategorii wiekowych nie były duże. Sprowadzały się one właściwie do niewielkich przesunięć, zaś kategoria „bez ograniczeń wiekowych" pod koniec dekady była stosowana sporadycznie. A przecież miała zachęcać dorosłych do wspólnego z dziećmi uczestnictwa w seansach filmowych. Zamiast kategorii „od jedenastu lat” wprowadzono kategorię „od dwunastu lat”. Kategorie: „od czternastu” i „od szesnastu” zastąpiono kategorią „od piętnastu lat”. Znikła kategoria „od siedmiu lat”, ale pozostała „od sześciu lat” i - oczywiście - „od lat osiemnastu". Ta statyczność systemu była w coraz większym stopniu niedostosowana do praktyki odbiorczej. Młodzi widzowie dzięki telewizji zyskali możliwość obejrzenia filmów, które były dla nich niedostępne w kinach ${ }^{71}$. W małych, pozbawionych filmów premierowych kinach bileterki często łagodnie traktowały obowiązek przestrzegania granic wieku. Można więc przypuszczać, że użyteczność systemu kategorii wiekowych w przeważającej mierze ograniczała się do regulowania organizacji seansów dla szkół.

JAKUB ZAJDEL

${ }^{1}$ Zob. Z. Bajka, Czytelnictwo prasy w Polsce Ludowej, Kraków 1976, s. 279-280.

2 Kina, „Trybuna Robotnicza”, 03.09.1973, nr 208 (9193), s. 6. Gdy dany film był wyświetlany w kilku kinach, to nie wymieniam ich, ponieważ tytuł filmu łatwo znaleźć w repertuarze.

3 Kina, „Trybuna Robotnicza”, 06.09.1973, nr 211 (9196), s. 4.

${ }^{4}$ K. G., Bielsko-Biała [bez tytułu], cyt. za, O. Sobański, Do lat szesnastu, „Film” 1973, nr 45, s. 2.
${ }^{5}$ Nadal ,,W pustyni i w puszczy”. Frekwencja na filmach polskich [niepodpisana notka], „Film” 1974, nr 27 (75), s. 2.

${ }^{6}$ Rekord ,W pustyni i w puszczy”. Frekwencja na filmach polskich [niepodpisana notka], „Film” 1974, nr 11 (59), s. 2.

${ }^{7}$ E. Smoleń-Wasilewska, Kluby filmowe - dzisiaj, „Film” 1970, nr 15 (1114), s. 7.

${ }^{8}$ Tamże, s. 7.

${ }^{9}$ Zob. W. Wierzewski [bez tytułu], ,Film” 1970, nr 19 (1118), s. 14.

${ }^{10}$ Tamże. 
${ }^{11}$ Zob. A. Misiak, Kinematograf kontrolowany. Cenzura filmowa $w$ kraju socjalistycznym $i$ demokratycznym (PRL i USA), Kraków 2006, s. 345-351.

${ }^{12}$ K. Żygulski, Widownia lat siedemdziesiatych, „Film” 1970, nr 44 (1143), s. 6.

13 Tamże, s. 6.

${ }^{14}$ Zob. Film jako wychowawca, rozmowa z udziałem Janiny Koblewskiej, Anny Tatarkiewicz, Kazimierza Kutza, Andrzeja Wajdy, Krzysztofa Zanussiego i Bolesława Michałka, opracowała Bożena Janicka, „Film” 1972, nr 27 (1230).

${ }^{15}$ Zob. K. Żygulski, Uwagi socjologa, „Film” 1972, nr 31 (1234).

${ }^{16}$ Zob. M. Kozakiewicz, Głosy o złym i dobrym wplywie, ,Film” 1972, nr 32 (1235).

${ }^{17}$ Zob. A. Helman, Niebezpieczna gwattowność czy niebezpieczne kłamstwo? „Film” 1970, nr 34 (1237).

${ }^{18}$ Film jako wychowawca... s. 7.

19 Redakcja, Zamiast konkluzji, „Film” 1972, nr 37 (1240), s. 7.

${ }^{20}$ A. Kaleta [bez tytułu], „Film” 1970, nr 30 (1129), s. 14.

${ }^{21}$ Zob. K. Żygulski, Uwagi socjologa, „Film” 1972, nr 31 (1234), s. 7.

${ }^{22}$ H. Depta, Film dozwolony od lat...? „Film” 1972, nr 40 (1243), s. 6.

${ }^{23}$ Tamże, s. 6.

${ }^{24}$ Tamże, s. 7.

${ }^{25}$ Tamże.

${ }^{26}$ Zob. H. Depta, Najważniejsza ze wszystkich sztuk, ,Film” 1973, nr 13; H. Depta, Najprzewrotniejsza ze wszystkich sztuk, „Film” 1973, nr 15.

${ }^{27}$ Zob. A. Helman, Niebezpieczna gwattowność czy niebezpieczne kłamstwo? „Film” 1970, nr 34 (1237).

${ }^{28}$ Tamże, s. 6.

${ }^{29}$ Tamże.

${ }^{30}$ H. Depta, Najprzewrotniejsza... s. 15.

${ }^{31}$ M. Beam, Seks na ziemi, terror $w$ powietrzu [nie podano nazwiska thumacza], ,Film” 1970, nr 39 (1138), s. 13.

32 Z. Tarkowski [bez tytułu], ,Film” 1971, nr 2 (1153), s. 14.

${ }^{33}$ M. M. Gliwice [bez tytułu], ,,Film” 1972, nr 44 (1247), s. 14

${ }^{34}$ Zob. Z. L. Starowicz, Kultura masowa a seks, „Tygodnik Powszechny” 1972, nr 9 (1205).

${ }^{35}$ Tamże, s. 5.

${ }^{36}$ Tamże.

${ }^{37}$ M. Karpiński, Alarm w sprawie seksu, „Film” 1972, nr 32 (1235), s. 10. Zob. Ł. Szymański, Dlaczego film polski wspina się na palce? „Film” 1973, nr 23.
${ }^{38}$ Dr K. Ł., Warszawa, ,,Dlaczego film polski wspina się na palce?” „Film” 1973, nr 28, s. 12.

${ }^{39}$ J. C. z Rzeszowa, Purytański ,Film”, ,Film” 1973, nr 34, s. 12.

${ }^{40}$ St. L. z Oświęcimia, Purytański ,Film”, „Film” 1973, nr 34, s. 12.

${ }^{41}$ M. Kozakiewicz, Głosy o ztym i dobrym wptywie, „Film” 1972, nr 32 (1235), s. 7.

${ }^{42}$ Kina, ,Trybuna Robotnicza”, 04.01.1972, nr 2 (8678), s. 4.

${ }^{43}$ Aby się zorientować, jak bardzo skomplikowany w odbiorze był film Trzecia część nocy, wystarczy przejrzeć polemikę Jerzego Płażewskiego z Januszem Gazdą, w której ten ostatni zarzucał Płażewskiemu staromodną metodę analizy filmu, a Płażewski bronił się, twierdząc, że nawet filmowa wizja musi być spójna, co w tym przypadku oznaczało, iż synteza czasu i przestrzeni musi opierać się na logicznych uogólnieniach, a nie na błędach narracyjnych i obsadowych. Zob. J. Płażewski, Czerwony filtr młodości, „Ekran” 1972, nr 2 (770); J. Gazda, Klęska tradycyjnych kryteriów opisu, „Ekran” 1972, nr 4 (772); J. Płażewski, Symbol źle dobrany, „Ekran” 1972, nr 5 (773); J. Gazda, Nie tylko instytut, „Ekran” 1972, nr 5 (773).

${ }^{44}$ Zob. ,, Trzecia część nocy”- Andrzej Żuławski na spotkaniu ze studentami, relacja Barbary Mruklik, „Kino” 1971, nr 12 (72).

${ }^{45} \mathrm{~S}$. Grzelecki, Uporać się z legenda, „Życie Warszawy", 8.01.1972, nr 6, s. 6.

${ }^{46}$ Zob. R. Marszałek, Świt Andrzeja Żuławskiego, „Literatura”, 24.02.1972, nr 2, s. 8; J. Zatorski, Apokalipsa i biologia, „Kierunki” 16.01.1972, nr 3 (813), s. 9; A. Tatarkiewicz, Arcydebiut, „Tygodnik Kulturalny”, 16.01.1972, nr 3 (762), s. 12.

${ }^{47} \mathrm{~J}$. Ambroziewicz, Trzecia część trądu, ,Argumenty", 16.01.1972, nr 3 (710), s. 16. Do tytułu recenzji Jerzego Ambroziewicza należy dodać krótkie wyjaśnienie, ponieważ sugeruje on całkowicie negatywną ocenę filmu Andrzeja Żuławskiego. Otóż Ambroziewicz ocenia w niej Trzecia czesść nocy i Trąd Andrzeja Trzosa-Rastawieckiego.

48 „Dobry smak dowodzi bezsity artysty”, z Andrzejem Żuławskim rozmawiał Mikołaj Wojciechowski, „Ekran” 1972, nr 3 (771), s. 5.

${ }^{49}$ Tamże, s. 5.

${ }^{50}$ A. P., Tomaszów Mazowiecki [bez tytułu], „Film” 1972, nr 19 (1222), s. 14.

${ }^{51}$ Mgr A. Kamieński [bez tytułu], „Film” 1972, nr 19 (1222), s. 14.

${ }^{52}$ M. Hermanowicz (Warszawa), List od czytelnika, „Kino” 1972, nr 6 (78), s. 22.

${ }^{53}$ L. Pijanowski, Erotyka, pruderia i inne zwiazane z tym sprawy, „Kino” 1971, nr 12 (72), 


\section{KATEGORIE WIEKOWE FILMÓW...}

s. 44; zob. L. Bukowiecki, Erotyka, erotyka, „Tygodnik Demokratyczny”, 25.07.1971, nr 30 (946), s. 5.

${ }^{54}$ O. Sobański, Do lat szesnastu, „Film” 1973, nr 45, s. 2.

${ }^{55}$ Tamże, s. 2.

${ }^{56}$ E. Tumidajewicz, Ełk [bez tytułu], „Film” 1972, nr 12 (1215), s. 14.

${ }^{57}$ Kierownictwo Kina „Polonia” w Ełku [bez tytułu], „Film” 1972, nr 18 (1221), s. 14.

58 J. Czerniakowski [bez tytułu], „Film” 1972, nr 26 (1229), s. 14.

${ }^{59}$ Zob. M. M. Gliwice [bez tytułu], „Film” 1972, nr 44 (1247), s. 14

${ }^{60}$ (Sob.) [Oskar Sobański], Od 1 października trzy kategorie filmów, „Film” 1974, nr 33 (81), s. 2 .

${ }^{61}$ Tamże, s. 2. Wystarczy zajrzeć do programów kin po 1 października 1974 r., a więc po dniu od którego zaczęło obowiązywać wspomniane rozporządzenie Ministra Kultury i Sztuki, aby przekonać się, że granic wiekowych wciąż było sporo. Na przykład (ograniczam się tylko do filmów polskich): w repertuarze kin opublikowanym 1 października 1974 r. filmy Potop i Gniazdo miały nową kategorię ,,bez ograniczeń", ale film Sami swoi (kino Lutnia, Sosnowiec) był przeznaczony dla widzów jedenastoletnich. Zob. Kina, „Trybuna Robotnicza”, 01.10.1974, nr 230 (9522), s. 3. Dwa tygodnie później filmy Potop, Janosik i $W$ pustyni i w puszczy wyświetlano z kategorią „,b.o.”, ale przy tytule Sami swoi napisano: od sześciu lat (kino Zryw, Gliwice), przy czym film Nie ma mocnych był oznaczony ,b.o.” (kina: Jutrzenka, Gliwice; Blask, Szopienice), a na film Anatomia miłości (kino Energetyk, Zabrze) wstęp mieli widzowie powyżej szesnastego roku życia mimo określonego rozporządzeniem ministra przedziału wiekowego piętnaście - osiemnaście lat. Zob. Kina. „Trybuna Robotnicza", 15.10.1974, nr 241 (9533), s. 3. W repertuarze kin wydrukowanym 3 grudnia 1974 r. można było przeczytać, że podniesiono granicę wieku dla filmów Potop i Gniazdo (kino Stal, Mikołów) „do sześciu lat”. Zob. Kina. „Trybuna Robotnicza”, 03.12.1974, nr 282 (9574), s. 5. Repertuar z dnia poprzedniego informował, że oba te filmy są dla wszystkich - „,b.o.”. Zob. Kina. ,Trybuna Robotnicza", 02.12.1974, nr 281 (9573), s. 6. Pomimo zapowiadanego uproszczenia systemu w drugiej połowie lat 70. nadal obowiązywały znane już wcześniej kategorie, na przykład na film Jarosław Dąrowski (kino Zorza, Kato- wice) mogli wejść widzowie od szóstego roku życia. Zob. Kina. „Trybuna Robotnicza”, 30.01.1976, nr 24 (9910), s. 4. Następnie film ten zniknął z ekranów na kilka miesięcy, by powrócić z kategorią: „,b. o.” (kino Silesia, Czechowice). Zob. Kina. „Trybuna Robotnicza", 10.09.1976, nr 207 (10.093), s. 5. Film Motylem jestem, czyli romans czterdziestolatka wiązał nową i starą kategorię wiekową. W dniu premiery, 10 września 1976 r., trzeba było mieć piętnaście lat (kino Rialto, Katowice), aby obejrzeć go w kinie, ale dzień później wystarczyło już lat sześć (kina: Bałtyk, Bytom; Marzenie, Zabrze). Zob. Kina. „Trybuna Robotnicza", 10.09.1976, nr 207 (10.093), s. 5; Kina. „Trybuna Robotnicza”, 11-12.09.1976, nr 208 (10.094), s. 11. Zdarzało się, że film tego samego dnia balansował pomiędzy dwiema kategoriami wiekowymi. Przykładem może być Con amore, który można było obejrzeć w Dąbrowie Górniczej w kinie Bajka, mając co najmniej dwanaście lat, ale w Szczyrku w kinie Beskid granicą wieku było lat piętnaście. Zob. Kina. „Trybuna Robotnicza”, 02.09.1976, nr 201 (10.087), s. 4. Trzeba zaznaczyć, że właśnie od września 1976 r. zaczęto coraz częściej stosować kategorię „od lat dwunastu", która zastąpiła wcześniejszą „od jedenastu lat".

${ }^{62}$ W. Skrzypczak, Kinomani „B. O.”, „Film” 1976, nr 22 (174), s. 2.

${ }^{63}$ Zrezygnowany, Chcemy chodzić do kina, „Film” 1975, nr 16 (116), s. 2.

${ }^{64}$ B. Kamiński, A dla rodziców? „Film” 1977, nr 28 (1492), s. 2.

${ }^{65}$ Zob. M. G., Wrocław [bez tytułu], „Film” 1971, nr 36 (1187), s. 14.

${ }^{66}$ A. Ledóchowski, Jak sobie pościelesz, „Film” 1975, nr 16 (116), s. 5. Film Ziemia obiecana był wyświetlany na Górnym Śląsku od 12 marca 1975 r. z kategorią: od osiemnastu lat. Kina. „Trybuna Robotnicza”, 12.03.1975, nr 59 (9655), s. 8. Ale od 28 marca 1975 r. film ten miał już kategorię: od piętnastu lat. Kina, ,Trybuna Robotnicza", 28.03.1975, nr 72 (9668), s. 4.

${ }^{67}$ A. Ledóchowski, Smuga mtodości, „Film” 1976, nr 21 (173), s. 3.

${ }^{68}$ Tamże, s. 4.

${ }^{69}$ Tamże.

${ }^{70}$ O. Sobański, Filmy dla dzieci - czy kino rodzinne? „Film” 1979, nr 13 (1582), s. 17.

${ }^{71}$ Zob. A. Ledóchowski, Smuga młodości, dz. cyt, s. 4. 